\title{
WARNA LOKAL JAWA DALAM NOVEL INDONESIA PERIODE 1980 - 1995
}

\author{
Hartono \\ FBS Universitas Negeri Yogyakarta \\ email: hartono-fbs@uny.ac.id
}

\begin{abstract}
Abstrak
Penelitian ini bertujuan mendeskripsikan wujud dan fungsi warna lokal Jawa dalam novel Indonesia periode 1980-1995. Secara purposif, diperoleh sumber data penelitian, yakni: novel Ronggeng Dukuh Paruk, Lintang Kemukus Dini Hari, Jantera Bianglala (Ahmad Tohari); Para Priyayi (Umar Kayam); Burung-Burung Manyar dan Durga Umayi (YB. Mangunwijaya); Canting (Arswendo Atmowiloto); Pasar (Kutowijoyo); dan Tirai Menurun (NH. Dini). Pengumpulan data dengan teknik baca dan catat. Analisis data dengan teknik deskriptif kualitatif. Hasil penelitian sebagai berikut. Pertama, warna lokal Jawa, berupa: latar tempat (Surakarta, Yogyakarta, Semarang, Magelang, Madiun, Temanggung, dan Muntilan); latar waktu (hari dan pasaran, Selasa Kliwon, Jumat Kliwon, sepasar, selapan, sewindu), kesenian (wayang, ketoprak, tayub, tembang); kepercayaan (Islam abangan, kepercayaan pada roh leluhur, mantra dan benda-benda pusaka); status sosial priyayi dan wong cilik; penggunaan bahasa (bahasa Jawa, penamaan, pasemon); dan penamaan tumbuhan dan hewan. Kedua, warna lokal Jawa berfungsi sebagai: (a) masalah pokok yang diceritakan, (b) hipogram alur dan tokoh cerita, dan (c) penguat pelukisan latar cerita.
\end{abstract}

Kata kunci: warna lokal, novel Indonesia, hipogram, Jawa

\section{JAVANESE LOCAL COLORS IN INDONESIAN NOVELS IN THE 1980-1995 PERIOD}

\begin{abstract}
This study aims to describe the forms and functions of Javanese local colors in Indonesian novels in the 1980-1995 period. The data sources were purposively selected; they were novels entitled Ronggeng Dukuh Paruk, Lintang Kemukus Dini Hari, Jantera Bianglala (Ahmad Tohari); Para Priyayi (Umar Kayam); Burung-Burung Manyar dan Durga Umayi (YB. Mangunwijaya); Canting (Arswendo Atmowiloto); Pasar (Kutowijoyo); and Tirai Menurun (NH. Dini). The data were collected through reading and note taking. They were analyzed by the qualitative descriptive technique. The results of the study are as follows. First, Javanese local colors include spatial setting (Surakarta, Yogyakarta, Semarang, Magelang, Madiun, Temanggung, and Muntilan); temporal setting (days and pasaran, Selasa Kliwon, Jumat Kliwon, sepasar, selapan, and sewindu); arts (wayang, ketoprak, tayub, and tembang); beliefs (nominal Islam and beliefs in ancestral spirits, mantras, and heirlooms); social statuses of nobility and common people; language use (Javanese language, naming system, and symbols); and plant and animal naming systems. Second, Javanese local colors serve as: (a) a main problem to narrate, (b) a hypogram of the plot and characters, and (c) an intensifier to the setting description.
\end{abstract}

Keywords: local colors, Indonesian novels, hypogram, Javanese 


\section{PENDAHULUAN}

Pada awal kelahirannya, novel Indonesia ditandai dengan adanya unsur budaya daerah (Rampan, 1984:4; Sumardjo, 1979:51). Novel Azab dan Sengsara karya Merari Siregar (1920) dan Sitti Nurbaya karya Marah Rusli (1922) merupakan contoh novel Indonesia yang mengandung warna lokal, yaitu Sumatra. Para sastrawan/novelis Indonesia awalnya memang banyak dari daerah dan hasil karya mereka banyak yang mengandung warna lokal daerah, terutama dari Sumatra. Hal ini terjadi karena sebagian besar mereka berasal dari daerah Sumatra.

Selanjutnya, sastrawan Indonesia pada periode 1970-an kembali banyak menulis novel yang mengangkat warna lokal daerahnya. Rosidi (1985:27), ketika mengumumkan lahirnya suatu angkatan terbaru tahun 60-an, menyebutkan salah satu ciri kuat angkatan tersebut adalah adanya orientasi nilai-nilai budaya daerah.

Penulisan novel berwarna lokal daerah mencapai puncaknya pada periode 1980-an. Pada saat itu, muncul banyak karya sastra dari berbagai daerah yang menunjukkan kekhasan warna lokal. Karya sastra seperti ini pada umumnya ditulis oleh pengarang yang berasal dari daerah yang bersangkutan. Korie Layun Rampan dalam Upacara (1978) menunjukkan kehidupan sosial budaya masyarakat Dayak. Ahmad Tohari dalam Ronggeng Dukuh Paruk (1982), Lintang Kemukus Dini Hari (1985), dan Jantera Bianglala (1986) menunjukkan kehidupan sosial budaya masyarakat Jawa khususnya daerah Banyumas. Demikian juga, Linus Suryadi A.G. dalam Pengakuan Pariyem (1981), Arswendo dalam Canting (1986), Umar Kayam dalam Sri Sumarah (1985) dan Para Priyayi (1990), Kuntowijoyo dalam Pasar (1994) dan NH. Dini dalam Tirai Menurun (1993) menunjukkan kehidupan sosial budaya masyarakat Jawa. Putu Wijaya dalam Bila Malam Bertambah Malam (1971) menunjukkan kehidupan sosial budaya masyarakat Bali.
Salah satu fenomena penulisan karya sastra di Indonesia pada periode 1980-an tersebut adalah adanya kecenderungan untuk mengangkat budaya daerah sesuai dengan latar belakang sosial-budaya demografi pengarang. Salah satu budaya daerah yang banyak diangkat ke permukaan itu adalah budaya Jawa (Nurgiyantoro, 1998: viii). Kenyataan bahwa banyak pengarang yang kembali ke akar budaya sebagai salah satu sumber penulisan karya kreatifnya merupakan hal yang wajar karena sastra Indonesia pada dasarnya adalah sastra lokal (Sayuti, 2012).

Teeuw mengatakan bahwa perkembangan kesusasteraan Indonesia telah kembali ke akar tradisi (Jamil, 1987:41). Menurutnya, sastra Indonesia modern tidak pernah putus hubungannya dengan sastra tradisi (Teeuw, 1982: 12). Ada kesinambungan antara sastra tradisi atau sastra lama dengan sastra Indonesia modern.

Sumardjo (1983), menyatakan bahwa pada dekade 80-an pusat dan orientasi kesusasteraan Indonesia ada kemungkinan beralih ke Jawa (tengah) setelah sebelumnya terfokus di Jakarta. Pada era 80-an, kecenderungan mengangkat warna lokal dalam sastra Indonesia mulai menguat. Salah satu pemicunya, menurut Sarjono (2005), adalah lahirnya dua novel yang fenomenal, yaitu Ronggeng Dukuh Paruk karya Ahmad Tohari yang sangat kuat warna lokalnya, dan juga Pengakuan Pariyem karya Linus Suryadi AG. yang juga penuh dengan lokalitas kedaerahan.

Menurut Darma (1995: 171), semakin jauh sastrawan melangkah, akan semakin dalam mereka kembali ke akar daerahnya karena subkebudayaan daerah itu merupakan salah satu unsur yang membentuk mereka. Menurutnya, semakin menasional dan menginternasional orientasi kepengarangan seorang penulis, sekaligus ia juga akan semakin menukik ke akar budayanya yang merupakan salah satu unsur sosial budaya yang telah membentuknya. Para pengarang yang dilahirkan 
dan dibesarkan dalam kebudayaan daerah masing-masing, setelah menjadi manusia Indonesia, merindukan kembali subkebudayaan yang telah membentuknya itu.

Novel Indonesia selalu menunjukkan kekhasan, unikum, dan hal itu berkaitan erat dengan kultur etnik yang telah lama ada pada diri pengarang dan mengalir menjadi pola berpikir, perilaku, dan sikap hidup, tata krama dan etika, tindakan dan ekspresi diri, pandangan dan orientasi tentang alam dan lingkungan, bahkan juga sampai pada wawasan estetikanya (Mahayana, 2007: 2).

Perkembangan karya sastra masih menyediakan tempat bagi karya yang mengungkapkan warna lokal di dalamnya. Misalnya, kumpulan cerpen Raudal Tanjung Banua yang berjudul "Parang Tak Berulu" yang menawarkan representasi dunia perempuan di tengah masyarakat Minangkabau, atau "Rumah Kawin"karya Nur Zen Hae yang berlatar kultur masyarakat Betawi, juga karya-karya Taufik Ikram Jamil yang mengungkapkan persoalan masyarakat Melayu-Riau (Murniah, 2006). Para sastrawan perlu menggali potensi lokal, baik bahasa, mitos, maupun sejarah lokal sebagai sumber penciptaan karya sastra di tengah-tengah arus globalisasi sekarang ini. Ada beberapa pengarang yang di dalam cerita-ceritanya tanpa memberi keterangan maksud kata-katanya memakai kata-kata Jawa, baik sebagai alat pemberi warna lokal maupun karena tidak ada padanan katanya dalam bahasa Indonesia (Sastrowardoyo, 2000:839).

Sastra Indonesia berwarna lokal adalah sastra Indonesia yang di dalamnya tergambar realitas sosial budaya suatu daerah yang ditunjuk secara langsung oleh fiksionalitas. Secara intrinsik dalam suatu karya sastra Indonesia berwarna lokal selalu dihubungkan dengan unsurunsur pembangkitannya, yaitu latar belakang, penokohan, gaya bahasa, dan suasana, adat istiadat, agama, kepercayaan, sikap, filsafat hidup, hubungan sosial, dan stuktur sosial (Purba, 2009).

Novel Indonesia pada periode 80 -an banyak mengungkap warna lokal di dalamnya, khususnya warna lokal Jawa. Mengapa budaya Jawa menjadi acuan atau sumber inspirasi bagi para sastrawan Indonesia? Bentuk warna lokal Jawa apa saja yang digunakan pengarang dalam karyanya. Pertanyaan tersebut tidak dapat dilepaskan dari kenyataan tentang Jawa. Menurut Kayam (2001:2) Jawa masih merupakan kekuatan faktual dalam konstelasi kehidupan di Indonesia, baik secara ekonomi, politik, sosial, maupun budaya. Karenanya, Jawa juga akan menjadi suatu kekuatan penting dalam konstelasi kehidupan regional maupun global.

Warna lokal Jawa dalam novel pada penelitian ini terkait dengan latar budaya masyarakat Jawa yang tercermin pada novel. Warna lokal Jawa berkaitan dengan budaya Jawa. Pengertian tersebut identik dengan pendapat Abrams (1981: 98) yang mengatakan bahwa warna lokal adalah lukisan mengenai latar, adat-istiadat, cara berpakaian, dan cara berpikir yang khas dari suatu daerah tertentu. Latar sosial budaya biasanya terwujud dalam tokoh-tokoh yang ditampilkan, sistem kemasyarakatan, adat istiadat, pandangan masyarakat, kesenian, dan benda-benda kebudayaan yang terungkap dalam karya sastra (Pradopo, 1987:234).

Warna lokal Jawa mengacu pada budaya lokal Jawa, budaya masyarakat Jawa (Endraswara, 2003). Masyarakat Jawa merupakan orang-orang yang bertempat tinggal, bergaul, dan berkembang di pulau Jawa yang kemudian mengembangkan tradisi dan kebudayaan yang khas dan berkarakteristik Jawa (Roqib, 2007:33). Masyarakat Jawa adalah orang yang secara geografis tinggal di pulau Jawa, tepatnya di provinsi Jawa Tengah, Daerah Istimewa Yogyakarta, dan Jawa Timur, bukan Jawa Barat, Banten, dan Jakarta yang dihuni oleh suku Sunda dan 
Betawi, dan bukan pula bagian Timur Jawa yang menggunakan bahasa Madura meskipun masih kategori subkultur Jawa. Mereka yang tinggal di daerah-daerah tersebut mengembangkan kebudayaan Jawa.

\section{METODE}

Sumber data penelitian ini adalah novel Indonesia yang diterbitkan dalam kurun waktu 1980 sampai tahun 1995 yang di dalamnya terungkap warna lokal Jawa. Selanjutnya, untuk menentukan subjek penelitian digunakan teknik purposif. Novel-novel yang dipilih sebagai subjek penelitian adalah novel yang di dalamnya dominan mengandung dan mengekspresikan unsur-unsur warna lokal Jawa lebih banyak sehingga tidak semua novel yang mengandung warna lokal Jawa menjadi subjek penelitian. Dengan pertimbangan tersebut ditentukan novelnovel yang dijadikan sumber data, yakni: (1) Ronggeng Dukuh Paruk (RDP), Lintang Kemukus Dini Hari (LKDH), dan Jantera Bianglala (JB) karya Ahmad Tohari; Para Priyayi (PP) karya Umar Kayam; Burung Burung Manyar (BBM) dan Durga Umayi (DU) karya YB. Mangunwijaya; Pasar (PAS) karya Kuntowijoyo; Canting (C) karya Arswendo Atmowiloto; dan Tirai Menurun (TM) karya N.H. Dini.

Pengumpulan data dalam penelitian ini dilakukan dengan teknik pembacaan dan pencatatan (baca catat). Novel yang telah dipilih dan dijadikan sumber data penelitian dibaca secara cermat dan teliti untuk menemukan warna lokal Jawa yang terkandung di dalamnya. Pembacaan dan pencatatan dilakukan secara berulangulang untuk menemukan warna lokal Jawa dalam novel tersebut.

Model analisis yang digunakan dalam penelitian ini adalah model analisis interaktif-dialektif (Saryono, 1998:268). Pengumpulan dan analisis data dikerjakan secara serempak, bolak-balik, dan berkali-kali sampai titik jenuh, sesuai dengan keperluan dan kecukupan, yaitu dihasilkannya sebuah pemahaman yang mendalam dan utuh tentang warna lokal Jawa dalam novel Indonesia periode 1980 - 1995. Kegiatan analisis data dilakukan dengan langkah-langkah sebagai berikut. Pertama, membaca untuk menghayati dan memahami secara mendalam seluruh sumber data dan data penelitian, kemudian menyeleksi dan menandainya dengan kode kutipan. Kedua, mengidentifikasi dan mengklasifikasikan seluruh data secara utuh dan menyeluruh berdasarkan butirbutir masalah yang telah dirumuskan, tidak melihat bagian per bagian. Ketiga, menafsirkan kembali secara semiotik seluruh data teridentifikasi dan terklasifikasi untuk menemukan kepadu-an, kesatuan, dan hubungan antardata sehingga diperoleh pemahaman utuh dan menyeluruh terhadap warna lokal Jawa dalam novel Indonesia.

\section{Wujud Warna Lokal Jawa dalam Novel Indonesia}

Dalam novel-novel Indonesia periode 1980-1995 dapat diketahui adanya tandatanda budaya, khususnya warna lokal yang menandai kondisi sosial budaya masyarakat Jawa. Tanda-tanda tersebut menyebar dalam unsur novel khususnya pada fakta cerita. Fakta cerita dalam novel yang berwarna lokal Jawa tampak dominan pada latar dan tokoh cerita. Oleh karena itu, dalam penelitian ini latar dan tokoh menjadi unsur utama yang dibahas selain unsur alur dan tema.

\section{Latar Tempat sebagai Warna Lokal}

Secara umum, latar tempat yang terdapat pada novel RDP, JB, dan LKDH adalah kampung dukuh Paruk. Penduduk kampung ini berasal dari keturunan $\mathrm{Ki}$ Secamenggala, seorang bromocorah yang mengasingkan diri. Penduduk kampung ini hidup miskin serba kekurangan.

Istilah 'Dukuh Paruk' merupakan suatu tanda yang memaknai nama sebuah 
kampung yang menunjukkan warna lokal Jawa yang khas. Latar Dukuh Paruk itu digambarkan terpencil dari daerah lain. Nama daerah ini menunjukkan warna lokal daerah di Jawa. Dukuh merupakan salah satu sebutan untuk sebuah wilayah di bawah wilayah kelurahan atau desa. Di Jawa, satu desa terdiri atas beberapa dukuh atau pedukuhan.

Dalam novel PP, latar tempat peristiwa yang menunjukkan warna lokal Jawa adalah Wonogalih Jawa Timur. Penyebutan kota Wanagalih, Kali Madiun, dan Bengawan Solo dalam novel Para Priyayi tersebut mengacu pada warna lokal daerah di Jawa. Pelukisan kota Wanagalih, sebagai kota kecil di Jawa Timur dengan kehidupan dan tradisi masyarakatnya memperjelas latar tempat dalam novel Para Priyayi. Wanagalih sebagai ibukota kabupaten tempat hidup dan bermasyarakat keluarga Sastrodarsono. Hal ini menunjukkan penggunaan nama tempat atau daerah sebagai unsur penanda warna lokal Jawa. Bengawan Solo merupakan nama sungai besar di Jawa yang melewati daerah Solo. Selain daerah Madiun dan Surakarta, Yogyakarta juga menjadi latar tempat dalam novel Para Priyayi. Surakarta dan Yogyakarta sebagai pusat budaya Jawa juga merupakan salah satu unsur warna lokal Jawa.

Dalam novel BBM, YB. Mangunwijaya menyebutkan daerah Magelang sebagai salah satu latar ceritanya selain Yogyakarta, Surakarta, dan Jakarta. Kehidupan Teto kecil di Magelang menjadi bagian dari novel tersebut. Daerah Magelang merupakan salah satu daerah yang ada di wilayah Jawa Tengah sebagai salah satu daerah pengembangan budaya atau warna lokal Jawa. Penggunaan nama tempat Magelang, Yogyakarta, Surakarta menunjukkan adanya warna lokal Jawa dalam novel tersebut.

Latar tempat dalam novel DU adalah Magelang, Kedu, dan daerah perjuangan sekitar Yogyakarta. Daerah pegunungan
Merapi, Merbabu, Telomoyo Sumbing Sindoro, Pegunungan Menoreh, Candi Borobudur, Mendut, dan Pawon adalah penunjuk lokasi daerah di Jawa, khususnya Jawa Tengah.

Dalam novel Canting, latar tempatnya sebagian besar terjadi di Pasar Klewer. Pasar tempat berjualan batik yang berada di daerah Surakarta Jawa Tengah. Nama Pasar Klewer tersebut menunjukkan adanya penggunaan warna lokal Jawa berupa nama sebuah pasar batik terbesar di Surakarta. Nama tempat, Pasar Klewer hanya ada di Surakarta Jawa Tengah, sebuah nama pasar yang terkenal sebagai sentra batik.

Latar tempat dalam novel TM adalah Temanggung, Salatiga, Muntilan, Madiun, Yogyakarta, dan Semarang. Sebelum menetap di kota Semarang, Paguyuban Wayang Orang Kridopangarso, telah melakukan pementasan keliling dari kota ke kota. Berawal dari Temanggung pada awal berdirinya (TM: 90), Paguyuban Kridopangarso pernah juga pentas di Pasar Malam yang diadakan di Madiun (TM: 126). Kemudian menetap di kota Semarang. Paguyuban Wayang Orang Kridopangarso juga pernah Pentas di Perayaan Sekaten Yogyakarta (TM: 343 - 344).

\section{Kesenian sebagai Warna Lokal}

Warna lokal Jawa dalam bentuk kesenian yang diungkapkan dalam novel $R D P$, $L K D H$, dan JB karya Ahmad Tohari yang utama adalah kesenian ronggeng. Seni ronggeng menjadi bagian utama yang diceritakan, termasuk upacara bukak klambu dan perannya sebagai seorang gowok. Kehidupan Srintil sebagai seorang ronggeng, suka dan dukanya diceritakan dalam novel dari awal sampai akhir. Selain itu, seni musik (calung dan siter), tembang Jawa, seni wayang juga diceritakan dalam novel-novel tersebut.

Dalam novel $P P$ warna lokal Jawa dalam bentuk kesenian yang utama adalah wayang dan tembang Jawa. Cerita wayang 
kulit Sumantri Ngenger menjadi hipogram alur cerita dan tokoh dalam novel $P P$, khususnya kehidupan priyayi Sastrodarsono dan Lantip. Wayang merupakan salah satu identitas manusia Jawa (Sardjono, 1985: 23) dan salah satu tindakan simbolik orang Jawa dalam bidang kesenian adalah wayang kulit (Herusatoto, 1984:98). Selain itu, tembang Jawa sebagai warna lokal Jawa dalam Serat Tripama juga dimanfaatkan oleh pengarang untuk menyampaikan nasihat melalui tokoh utamanya, yaitu Sastrodarsono. Selain wayang dan tembang Jawa, seni tari ledek juga diceritakan dalam novel $P P$.

Bentuk kesenian sebagai warna lokal Jawa dalam novel BBM dan DU adalah cerita wayang. Pada kedua novel ini ceritanya diawali dengan cuplikan cerita wayang yang diberi judul 'prawayang'. Cerita dalam prawayang inilah yang menjadi hipogram cerita novel. Dalam novel $B B M$, nama tokoh dan karakternya berhipogram pada cerita wayang, sedangkan pada novel $D U$ karakter tokoh utamanya berhipogram pada karakter tokoh cerita wayang. Namun demikian, ada juga karakter tokoh wayang yang didekonstruksi seperti tokoh Gatotkaca yang digambarkan sebagai kesatria yang dilukiskan sebagai laki-laki yang sukanya terbang dan berkelahi saja. Gatotkaca diperbandingkan dengan tokoh punakawan, yaitu Gareng, Petruk, dan Bagong. Hal ini dapat merendahkan atau melemahkan kelebihan atau kesaktian Gatotkaca (Mashuri, 2013: 25).

Dalam novel Canting, seni batik menjadi salah satu bentuk warna lokal Jawa yang utama. Selain seni batik, bentuk kesenian yang lain seperti tembang Jawa, seni tari ledek, dan keroncong juga diungkapkan dalam cerita. Usaha batik Bu Bei dari kejayaannya sampai surut bahkan hampir bangkrut kemudian dikelola oleh $\mathrm{Ni}$, anaknya sampai bangkit kembali diungkapkan dari awal sampai akhir cerita. Seni batik diceritakan dalam novel, mu- lai batik tulis sampai batik printing atau batik cap.

Kesenian wayang juga menjadi bentuk warna lokal Jawa dalam novel Tirai Menurun. Wayang dalam novel TM adalah bentuk seni wayang orang. Dalam novel TM, diceritakan pasang surut perkembangan paguyuban wayang orang Kridopangarso mulai dari awal berdirinya sampai menjelang bubar karena tokoh-tokoh pendukung utama paguyuban wayang orang tersebut meninggal. Seni tari, tembang, dan gamelan juga diungkapkan dalam novel tersebut.

\section{Sistem Religi/Kepercayaan sebagai Warna Lokal}

Masyarakat Jawa yang digambarkan dalam novel $R D P$, JB, dan $L D H$ khususnya masyarakat di Dukuh Paruk, percaya pada adanya Tuhan dan mempercayainya, tetapi juga masih percaya pada hal-hal mistis, kekuatan gaib alam semesta, rohroh halus, khususnya roh leluhur makam Ki Secamenggala. Mereka percaya bahwa arwah leluhurnya Ki Secamenggala memiliki pengaruh dan peran yang besar dalam kehidupan masyarakat dukuh Paruk.

Orang Dukuh Paruk percaya bahwa roh leluhurnya, Ki Secamenggala berpengaruh pada kehidupannya. Orang Dukuh Paruk juga percaya pada mantra-mantra (RDP: 22, 68) percaya pada tuah dari benda pusaka (keris) (RDP: 60 - 64). Bagi orang Jawa, keris merupakan salah satu benda pusaka yang memiliki kekuatan magis. Sebagaimana keris Jaran Guyang yang diberikan Rasus kepada Srintil merupakan pusaka seorang ronggeng di Dukuh Paruk. Walaupun keris bukan benda keramat, tetapi tidak sedikit yang dikeramatkan orang (Koesni, 2003:2).

Dalam novel Canting, Bu Bei dan Pak Bei digambarkan sebagai penganut abangan. Mereka percaya kepada Tuhan dan menyadari sangkan paran mereka adalah Tuhan. Pada saat kelahiran anak, ada acara procotan, brokohan, juga ada acara 
sepasaran, selapan. Bu Bei selalu bersyukur atas segala yang diterimanya baik musibah maupun berkah.

Pada novel Pasar, Pak Mantri Pasar digambarkan sebagai orang yang "benarbenar masih tulen Jawa" dan menjadi orang Jawa tetapi tetap berpegang teguh pada ajaran agama Islam. Pak Mantri berusaha benar-benar mengamalkan perintah agama Islam. Kepada Paijo, Pak Mantri menyampaikan wejangan-wejangan dari agama Islam. Bagaimana seseorang yang beragama Islam mengendalikan dirinya, terutama dalam mengendalikan hawa nafsu yang ada dalam dirinya yang selalu mempengaruhi segala perilaku kesehariannya. Pada novel Pasar, juga digambarkan karakter orang Jawa yang percaya pada adanya hari baik dan hari jelek. Adanya candrasengkala.

Dalam novel Tirai Menurun, diceritakan kepercayaan yang dianut oleh para tokohnya, yaitu agama Islam. Akan tetapi Islam yang kurang taat, misalnya, dalam melaksanakan salat, mereka tidak melakukan secara rutin sebagaimana tuntunan yang ada. Mereka juga puasa ngebleng. Dalam Islam, tidak dikenal adanya puasa ngebleng, yaitu puasa terus menerus selama beberapa waktu. Masyarakat dalam novel Tirai Menurun juga diceritakan masih sering mengadakan upacara selamatan. Upacara selamatan untuk kelahiran, kematian, maupun acara-acara lain.

\section{Sistem Kemasyarakatan/Status Sosial sebagai Warna lokal}

Warna lokal Jawa yang berbentuk status sosial dalam novel $R D P, J B$, dan $L K D H$ tampak pada jenis pekerjaan tokohtokohnya. Jenis pekerjaan masyarakat dalam novel Ronggeng Dukuh Paruk sesuai dengan jenis pekerjaan masyarakat Jawa. Sebagian masyarakat Jawa menekuni pekerjaan sebagai pedagang, petani, dan buruh tani. Pekerjaan yang disebutkan dalam novel Ronggeng Dukuh Paruk yang khas menggambarkan warna lokal Jawa adalah penari ronggeng, pedagang, pembuat tempe bongkrek, petani, dan buruh tani.

Sistem kemasyarakatan yang diungkap dalam novel Para Priyayi adalah golongan masyarakat priyayi dan juga wong cilik. Kehidupan priyayi dan wong cilik ini menjadi masalah pokok yang diungkap dan dikisahkan dalam novel tersebut. Dalam novel PP status sosial yang digambarkan adalah status priyayi dan orang biasa. Pada novel PP digambarkan kehidupan keluarga priyayi Sastrodarsono. Sebagaimana judul novel tersebut, kehidupain priyayi menjadi topik utama yang diceritakan di dalamnya. Bagaimana orang biasa bisa menjadi priyayi dan juga anak priyayi yang akhirnya menjadi orang biasa dideskripsikan melalui alur cerita secara lengkap.

Sistem kemasyarakatan/status sosial dalam novel Canting berkaitan dengan keluarga Pak Bei yang merupakan keluarga priyayi karena keturunan. Pak Bei masih keluarga ningrat, keluarga kraton. Pak Bei menikahi wanita dari keluarga biasa, keluarga wong cilik. Novel Canting bercerita tentang kehidupan keluarga priyayi dalam mempertahankan perusahaan batiknya. Tokoh ceritanya adalah golongan priyayi dan wong cilik sebagai buruh batik.

Status sosial dalam novel Pasar berkisah tentang kehidupan priyayi, Pak Mantri Pasar. Sebagai seorang priyayi, Pak Mantri Pasar memiliki sifat dan sikap pasrah. Sikap pasrah juga disampaikan Pak Mantri Pasar ketika memberikan nasihat kepada Paijo. Menurutnya, orang yang pasrah, tanpa pamrih adalah orang yang tidak ngoyo ngongso-ongso. Sebagai seorang priyayi, Pak Mantri Pasar selalu berusaha berbuat dan berperilaku sebagaimana perilaku seorang priyayi Jawa. Selain menggambarkan kehidupan Pak Mantri Pasar digambarkan juga kehidupan pembantunya, Paijo sebagai wong 
cilik yang bertugas sebagai penarik karcis di pasar. Sebagai wong cilik, Paijo selalu berusaha untuk mengabdi dan hormat kepada Pak Mantri.

\section{Penggunaan Bahasa Jawa sebagai Warna Lokal}

Dalam novel RDP, $L K D H$, dan $J B$ banyak digunakan bahasa Jawa dalam komunikasi antartokoh dan bahasa umpatan pada tokoh lain. Bahasa Jawa banyak digunakan, terutama istilah-istilah terkait dengan ronggeng. Istilah-istilah khusus yang menunjukkan warna lokal Jawa dari penggunaan bahasa juga banyak. Lagu-lagu yang dinyanyikan Srintil sebagai ronggeng juga menggunakan bahasa Jawa.

Tembang-tembang yang dinyanyikan oleh Srintil kecil menggunakan bahasa Jawa. Srintil dan kawan-kawan bermainnya juga belum paham pada apa yang dinyanyikan terutama isi maknanya. Tembang-tembang cabul yang seharusnya hanya dinyanyikan oleh orang dewasa tetapi Srintil menyanyikannya dengan tepat.

Penggunaan bahasa Jawa sebagai warna lokal Jawa dalam novel Para Priyayi cukup banyak. Pada tembang, yang merupakan salah satu warna lokal Jawa digunakan bahasa Jawa. Demikian juga komunikasi antartokoh kadang juga menggunakan bahasa Jawa. Kata-kata Ndoro, Embah Kakung, Embah Putri menunjukkan adanya penggunaan bahasa Jawa. Sebagai contoh penggunaan bahasa Jawa, misalnya kosakata abdi dalem, didhawuhi (PP: 3), pakde, kungkum (PP: 6,7, 44), wong cilik $(P P ; 44)$, dan masih banyak lagi. Tembang yang digunakan juga berbahasa Jawa.

Bahasa Jawa juga banyak digunakan dalam novel Burung-Burung Manyar. Karena banyaknya bahasa Jawa yang digunakan, pengarang sampai menambahkan catatan kaki untuk menjelaskan bahasa Jawa tersebut. Bahasa Jawa digunakan apa adanya, bahasa Jawa untuk umpatan kepada lawan bicara juga digunakan dengan baik tanpa ditutup-tutupi. Bahasa Jawa pasemon juga digunakan dalam novel ini (BBM: 264).

Dalam novel Durga Umayi selain penggunaan bahasa Jawa, juga penggunaan kerata basa untuk nama tokoh ceritanya. Nama Iin Sulinda Pertiwi sebagai kerata basa yang berarti tanah air Indonesia. Nama ibu Iin Sulinda Pertiwi, yaitu Legimah adalah perpaduan dari kata Jemuah Legi. Ibunya lahir pada hari Jumat Legi. Nama Legimah, sebuah nama khas bahasa Jawa. Demikian juga nama adik kembar dampitnya Iin, yaitu Brojol. Kata brojol dalam bahasa Jawa berarti keluar dengan lancar tanpa halangan yang berarti.

Dalam novel Canting, penggunaan bahasa Jawa tampak pada kehidupan Pak Bei. Sebagai masyarakat golongan priyayi Jawa, keluarga Pak Bei dalam berkomunikasi masih sering menggunakan bahasa Jawa. Bahasa Jawa yang digunakan para tokoh dalam novel Canting juga memperhatikan tingkatan tutur, dari bahasa Ngoko sampai bahasa krama, tergantung siapa yang berkomunikasi. Berdasarkan tingkat tuturnya bahasa Jawa dibagi dalam lima tingkatan dari bahasa Jawa Ngoko sampai Krama Inggil (Poedjosoedarmo, dkk. via Marsono, 2009: 21)

Bahasa Jawa dalam novel Pasar tampak ketika menulis tembang, Pak Mantri Pasar menggunakan bahasa Jawa, bahkan juga menggunakan tulisan Jawa. Selain bahasa Jawa dan pepatah Jawa, pengarang juga menggunakan bahasa Jawa dalam penamaan para tokohnya. Dalam pepatah Jawa disebutkan "urip iku mung mampir ngombe". "Hidup itu hanya mampir minum" tapi Kasan Ngali mengartikannya dengan makna yang berbeda. Dimaknai sebaliknya, karena hanya mampir minum, maka minumlah sebanyak-banyaknya.

Dalam novel Tirai Menurun, bahasa Jawa tampak melalui istilah-istilah dalam seni tari. Istilah itu antara lain: tawing, 
nyempurit ataukah njimprit, tanjak, tayung. Novel Tirai Menurun mengangkat wayang orang dalam ceritanya. Kehidupan para pemain wayang orang menjadi bahan cerita. Wayang orang sebagai bentuk seni khas Jawa pada saat novel tersebut ditulis sudah mulai pudar atau sudah sulit berkembang.

\section{Nama Tumbuhan dan Hewan sebagai Warna Lokal}

Dalam novel RDP, LKDH, dan JB banyak digunakan nama-nama tumbuhan dan hewan yang khas dari Jawa. Sebutan tumbuhan dan hewan tersebut hanya terdapat dalam istilah atau bahasa Jawa atau warna lokal Jawa. Dalam novel Ronggeng Dukuh Paruk, Ahmad Tohari menggunakan berbagai macam nama tumbuhan dan binatang yang ada di Jawa, nama-nama yang khas Jawa. Tumbuhan dan binatang tersebut di daerah lain juga ada, akan tetapi nama dan sebutannya berbeda. Nama tumbuhan seperti krokot, adalah nama tumbuhan khas Jawa yang biasanya tumbuh di sawah atau ladang pada musim kemarau. Jenis tumbuhan ini di Jawa dimanfaatkan sebagai sayur ataupun makanan ternak.

Demikian juga sebutan binatang, nama burung celepuk adalah nama burung khas Jawa. Sebutan binatang kampret juga khas Jawa, yaitu sebutan untuk kelelawar. Nama-nama tersebut antara lain adalah nama binatang gangsir, kepik hijau, celeng, burung ciplak, burung bence dan branjangan. Nama tumbuhan antara lain:senthe urang dan lompong bandung.

Binatang gansir, kepik hijau, burung bence merupakan nama-nama binatang khas Jawa. Demikian juga nama binatang celeng, senthe, dan lainnya. Di daerah lain juga ada hewan-hewan tersebut tetapi namanya berbeda-beda. Nama burung branjangan, ciplak, dan burung prenjak merupakan nama burung khas Jawa. Nama-nama burung yang ada di Jawa.

\section{Fungsi Warna Lokal Jawa dalam Novel Indonesia}

Banyak warna lokal Jawa yang ada dalam novel Indonesia periode 1980 1995. Berbagai warna lokal Jawa dalam novel-novel tersebut memiliki fungsi yang berbeda-beda tetapi secara umum sebagian besar berfungsi sebagai materi atau bahan cerita tidak hanya sebagai latar cerita saja.

Novel RDP memanfaatkan kisah kehidupan Srintil sewaktu masih kecil sebagai calon ronggeng sampai acara adat wisuda ronggeng dengan upacara bukak klambu sebagai isi cerita. Kesenian ronggeng merupakan salah satu bentuk seni khas Jawa sebagai bentuk warna lokal Jawa. Dalam novel RDP berbagai bentuk seni baik seni musik maupun seni suara (musik calung dan tembang Jawa) berfungsi untuk memperkuat pelukisan inti cerita, yaitu masalah ronggeng di Dukuh Paruk. Demikian juga penggunaan mantra dan dukun serta pelaksanaan upacara adat di makam Ki Secamanggala juga berfungsi untuk memperkuat warna lokal Jawa berupa seni ronggeng tersebut. Acara bukak klambu hanya dapat dilihat pada seni ronggeng di Dukuh Paruk.

Pada novel $L K D H$ yang merupakan kelanjutan cerita tentang rongeng di Dukuh Paruk masih mengangkat warna lokal Jawa seni ronggeng sebagai isi ceritanya. Perjuangan Srintil sebagai tokoh utama dalam menjalani hidup sebagai seorang ronggeng. Dia harus mau melayani lelaki yang mampu membayarnya. Tidak hanya untuk menari sebagai ronggeng tetapi sampai melayaninya di kamar. Kisah peran Srintil sebagai ronggeng yang menjalankan tugasnya sebagai gowok untuk Waras juga berfungsi untuk memperkuat pengisahan seni ronggeng tersebut.

Novel JB adalah novel terakhir yang bercerita tentang kehidupan seni ronggeng dengan tokoh utama Srintil dan Rasus. Dalam novel ini, warna lokal Jawa juga berfungsi sebagai isi cerita yang dikisah- 
kan. Tembang Jawa yang dinyanyikan ronggeng juga berfungsi untuk lebih memperkuat pelukisan latar cerita tentang seni ronggeng. Demikian juga masalah mantra dan kepercayaan kepada bendabenda pusaka seperti keris yang diceritakan dalam novel ini juga berfungsi untuk mendukung masalah pokok dalam novel JB, yaitu kehidupan ronggeng.

Warna lokal Jawa dalam novel Para Priyayi adalah priyayi itu sendiri. Novel PP dari awal sampai akhir berkisah tentang kehidupan seorang priyayi mulai dari awal sebagai seorang priyayi, kehidupan keluarga priyayi, sampai akhir hidupnya sebagai seorang priyayi. Kehidupan priyayi Jawa yang dikisahkan dalam novel PP berfungsi sebagai tema cerita. Selain kehidupan priyayi, warna lokal Jawa yang lain dan dominan adalah cerita wayang. Cerita wayang, Sumantri Ngenger menjadi hipogram cerita novel PP terutama alur ceritanya. Kehidupan tokoh utama novel PP seperti jalan kehidupan Sumantri dalam cerita wayang Sumantri Ngenger.

Novel Burung-Burung Manyar berkisah tentang kehidupan Larasati (Atik) dan Setadewa (Teto) dari kecil sampai dewasa. Warna lokal Jawa yang dominan dalam novel BBM tersebut adalah cerita wayang dan adat kehidupan orang Jawa. Kehidupan Larasati dan Setadewa berhipogram pada cerita wayang yang ditampilkan pengarang dalam pengantar cerita dengan judul 'prawayang'. Nama Larasati dan Setadewa diambil dari nama tokoh wayang Rarasati dan Baladewa. Karakter kedua tokoh tersebut juga hampir sama. Warna lokal Jawa cerita wayang dalam novel BBM berfungsi sebagai hipogram cerita terutama pada nama tokoh dan karakternya. Penggunaan warna lokal Jawa yang lain berupa penggunaan bahasa Jawa, pasemon, kepercayaan, tempat semuanya mendukung latar cerita.

Warna lokal Jawa berupa cerita wayang dalam novel $D U$ berfungsi sebagai hipogram terutama karakter tokoh utamanya, yaitu Iin Sulinda Pertiwi sebagai Dewi Uma yang berwatak baik dan Batari Durga yang berwatak jahat. Warna lokal yang lain yang berupa kepercayaan masyarakat Yogyakarta kepada cerita Nyai Roro Kidul dan Mbah Petruk Gunung Merapi berfungsi sebagai penguat latar cerita.

Novel Canting berkisah tentang kehidupan keluarga besar Raden Ngabehi Sestrokusuma, keluarga priyayi dengan perusahaan batiknya cap Canting. Warna lokal Jawa dalam novel ini adalah priyayi dan batik. Kisah tentang kehidupan priyayi dan batik dalam novel Canting berfungsi sebagai isi atau materi cerita. Cerita tentang perusahaan batik yang dikelola keluarga khususnya Bu Bei menjadi isi cerita novel dari awal sampai akhir. Warna lokal Jawa yang lain misalnya ajaran $\mathrm{Ki}$ Suryamentaram, kepercayaan, upacara adat, penggunaan bahasa Jawa, tembang Jawa dan seni tayub berfungsi untuk memperkuat latar cerita.

Novel Pasar berkisah tentang kehidupan seorang priyayi Mantri Pasar dan Paijo sebagai tukang penarik karcis kepada pedagang di pasar. Warna lokal Jawa dalam novel Pasar adalah kehidupan priyayi. Fungsi warna lokal Jawa dalam novel ini adalah sebagai isi atau materi cerita. Kehidupan Pak Mantri Pasar bersama Paijo yang berkonflik dengan Kasan Ngali, Zaitun, dan para pedagang di pasar diceritakan dari awal sampai akhir novel. Pandangan hidup Pak Mantri sebagai priyayi Jawa, tembang Jawa, tulisan Jawa, falsafah hidup orang Jawa, dan penggunaan bahasa Jawa yang ada dalam novel berfungsi sebagai penguat pelukisan latar cerita tentang priyayi.

Novel Tirai Menurun berkisah tentang kehidupan anggota Paguyuban Wayang Orang Kridopangarso di kota Semarang. Warna lokal Jawa ini berfungsi sebagai isi atau materi cerita dalam keseluruhan novel. Warna lokal Jawa yang lain berupa seni tari, musik gamelan, tembang Jawa, upacara adat, wayang kulit, dalang, dan 
seni tari ledek berfungsi sebagai penguat pelukisan latar cerita baik latar tempat maupun latar sosial budaya sehingga latar ceritanya menjadi lebih alami dan mendukung inti ceritanya.

\section{SIMPULAN}

Berdasarkan uraian hasil dan pembahasan dapat dikemukakan simpulan penelitian sebagai berikut. Pertama, warna lokal Jawa dalam novel Indonesia periode 1980 - 1995 terdiri atas warna lokal latar tempat (Surakarta, Yogyakarta, Semarang, Magelang, Madiun, Temanggung, dan Muntilan) sesuai daerah asal pengarangnya, latar waktu (hari dan pasaran, Selasa Kliwon, Jumat Kliwon, sepasar, selapan, mitoni, sewindu), kesenian Jawa (wayang, ketoprak, tayub/ledek, tembang, seni batik), kepercayaan (Islam abangan, kepercayaan pada roh leluhur, mantra, dan bendabenda pusaka), status sosial priyayi dan wong cilik, penggunaan bahasa Jawa (bahasa Jawa, nama orang/tokoh, pasemon), dan penamaan tumbuhan dan hewan. Kedua, warna lokal Jawa dalam novel Indonesia periode 1980-1995, sebagian besar berfungsi sebagai (1) masalah pokok atau isi keseluruhan cerita dalam novel, (2) hipogram alur dan karakter tokoh novel, dan (3) sebagai penguat pelukisan latar cerita. Wayang menjadi salah satu bentuk warna lokal Jawa yang banyak digunakan oleh pengarang novel Indonesia periode 1980-1995. Seluruh novel yang diteliti memanfaatkan wayang, hanya kadar pemanfaatannya yang berbeda-beda.

\section{UCAPAN TERIMA KASIH}

Artikel ini disarikan dari Disertasi yang berjudul Warna Lokal Jawa dalam Novel Indonesia Periode 1980 - 1995 pada Program Pascasrajana Universits Gadjah Mada Yogyakarta. Ucapan terima kasih disampaikan kepada: (1) Prof. Dr. Rachmat Djoko Pradopo dan (2) Prof. Dr. Marsono, S.U. selaku Promotor dan Kopromotor. Ucapan terima kasih juga disampaikan kepada Tim Penilai Kelayakan Disertasi dan Dewan Penguji yang telah berkenan memberikan saran dan masukan untuk perbaikan tulisan ini.

\section{DAFTAR PUSTAKA}

Abrams, M.H. 1981. A Glossary of Literary Terms. Cet. IV. New York: Holt, Rinehart and Winston.

Atmowiloto, Arswendo. 1986. Canting. Jakarta: Gramedia.

Darma, Budi. 1995. Harmonium. Yogyakarta: Pustaka Pelajar.

Dini, NH. 1993. Tirai Menurun. Jakarta: Gramedia.

Herusatoto, B. 1984. Simbolisme dalam Budaya Jawa.Yogyakarta: PT. Hanindita.

Endraswara, Suwardi. 2003. Falsafah Hidup Jawa. Yogyakarta: Cakrawala.

Jamil, Taufik Ikram. 1987. "Wawancara A. Teeuw: Jawanisasi Kesusasteraan Indonesia", dalam Horison, No. 2, Februari.

Kayam, Umar. 2001. Kelir Tanpa Batas. Yogyakarta: Gama Media.

Kayam, Umar. 1992. Para Priyayi. Jakarta: Pustaka Utama.

Koesni. 2003. Pakem Pengetahuan tentang Keris. Semarang: Aneka Ilmu.

Kuntowijoyo. 2004. Raja, Priyayi, dan Kawula. Yogyakarta: Ombak.

Kuntowijoyo. 1994. Pasar. Yogyakarta: Bentang.

Mahayana, S. Maman. 2007. 9 Jawaban Sastra Indonesia, Sebuah Orientasi Kritik. Jakarta: Bening Publising.

Mangunwijaya, YB. 1981. Burung-Burung Manyar. Jakarta: Djambatan.

Mangunwijaya. 1991. Durga Umayi. Jakarta: Pustaka Utama Grafiti.

Marsono. 2009. "Bahasa dan Budaya Jawa: Tinjauan Diakronis dan Wilayah Penyebarannya". Kreativity, Minda Melayu-Jawa dalam Khasanah Bahasa, Sastera, dan Budaya. Malaysia: Universitas Kebangsaan Malaysia.

Mashuri. 2013. "Dekonstruksi Wayang dalam Novel Durga Umayi". Poetika, 
Jurnal Ilmu Sastra. Prodi S2 Ilmu Sastra FIB UGM, Vol 1, No. 1, Juli 2013.

Murniah, Dad. 2006. “Warna Lokal dalam Sastra Indonesia". Makalah. Konferensi Internasional Kesusasteraan XVII HISKI.

Nurgiyantoro, Burhan. 1998. Transformasi Unsur Pewayangan dalam Fiksi Indonesia. Yogyakarta: Gadjah Mada University Press.

Pradopo, Rahmat Djoko. 1987. Pengkajian Puisi. Yogyakarta: Gadjah Mada University Press.

Purba, Antilan. 2009. Sastra Indonesia Berwarna Lokal.(http://antilan. blogspot. Com/2009/08/sastra-indonesia-berwarna-lokal.html). (Diunduh 5 Februari 2010).

Rampan, Korrie Layun. 1978. Upacara. Jakarta: Pustaka Jaya.

Rampan, Korrie Layun. 1984. “Warna Dasar Novel Indonesia Mutakhir", dalam Horison, No. 1, Januari.

Roqib, Moh. 2007. Harmoni dalam Budaya Jawa. Yogyakarta: Pustaka Pelajar.

Rosidi, Ayip. 1985. Kapankah Kesusasteraan Indonesia Lahir?. Jakarta: Gunung Agung.

Sarjono, Agus R. 2005. “Nasionalisme Indonesia vs Budaya Daerah dalam Perspektif Sastra Indonesia. Makalah.
Saryono, Djoko. 1998. Representasi Nilai Budaya Jawa dalam Prosa Fiksi Indonesia. Malang: Program Pascasarjana, IKIP Malang (Disertasi, tidak terbit).

Sardjono, Maria A. 1995. Paham Jawa. Jakarta: Sinar Harapan.

Sastrowardoyo, Soebagio. 2000. “Jagad Jawa Seharusnya Ditulis dalam Bahasa Jawa" dalam Sumber Terpilih Sejarah Sastra Indonesia Abad XX (E. Ullrich Kratz). Jakarta: Kepustakaan Populer Gramedia.

Sayuti, Sumito A. 2012. "Pengajaran Sastra dan Kearifan Lokal". Makalah Seminar Internasional PIBSI XXXIV. Unsoed Purwokerto, 30-31 Oktober 2012.

Sumardjo, Jakob. 1979. Masyarakat dan Sastra Indonesia. Yogyakarta: Nur Cahaya.

Sumardjo, Jakob. 1982. Pengantar Novel Indonesia. Jakarta: Karya Unipress.

Teeuw, A. 1982. Khazanah Sastra Indonesia. Jakarta: Balai Pustaka.

Teeuw, A. 1984. Sastra dan Ilmu Sastra. Jakarta: Pustaka Jaya.

Tohari, Ahmad. 1982. Ronggeng Dukuh Paruk. Jakarta: Gramedia.

Tohari, Ahmad. 1985. Lintang Kemukus Dini Hari. Jakarta: Gramedia.

Tohari, Ahmad. 1986. Jantera Bianglala. Jakarta: Gramedia. 